\title{
A SYSTEMATIC REVIEW AND META-ANALYSIS OF THREE CLINICAL TRIALS WITH ACCEPTANCE AND COMMITMENT THERAPY FOR PROBLEMATIC PORNOGRAPHY USE
}

\section{SYSTEMATYCZNY PRZEGLĄD I METAANALIZA TRZECH BADAŃ KLINICZNYCH DLA ZBADANIA SKUTECZNOŚCI TERAPII AKCEPTACJI I ZAANGAZZOWANIA W LECZENIU PROBLEMOWEGO UŻYWANIA PORNOGRAFII}

\author{
Masumeh Ghazanfarpour ${ }^{1}$ ID, Masoudeh Babakhanian ${ }^{2}$ ID , Abbas Keshtkar ${ }^{3}$, Mohammadali Kiani ${ }^{4}$ \\ ${ }^{1}$ Student Research Committee, Kerman University of Medical Sciences, Kerman, Iran \\ ${ }^{2}$ Abnormal Uterine Bleeding Research Center, Semnan University of Medical Sciences, Semnan, Iran \\ ${ }^{3}$ Tehran University of Medical Sciences, Tehran, Iran \\ ${ }^{4}$ Department of Pediatrics, Faculty of Medicine, Mashhad University of Medical Sciences, Mashhad, Iran
}

Alcohol Drug Addict 2020; 33 (3): 275-282 DOI: https://doi.org/10.5114/ain.2020.101802

\begin{abstract}
Introduction: Pornography use is at once a widespread and understudied practice. In this study, we explore the role of the Acceptance and Commitment Therapy (ACT) on treating problematic pornography viewing.

Material and methods: We searched controlled trials (CTs) articles on the effect of ACT on treating problematic pornography use (PPU). We searched the Cochrane Central Register of Controlled Trials (CENTRAL), MEDLINE
\end{abstract}

Streszczenie

Wprowadzenie: Używanie pornografii jest praktyką powszechną, ale niedostatecznie zbadaną. Autorzy pracy analizują rolę terapii akceptacji i zaangażowania (ACT) w leczeniu problemowego oglądania pornografii.

Materiał i metody: Autorzy szukali artykułów dotyczących badań kontrolowanych (CTs) na temat skuteczności ACT w leczeniu problemowego używania pornografii (PPU). W tym celu posłużyli się Cochrane Central Register of Con-

Correspondence to/Adres do korespondencji: Masoudeh Babakhanian, Abnormal Uterine Bleeding Research Center, Semnan University of Medical Sciences and Health Services, Bassij Blvd, Semnan, Iran, phone: +982335225141, e-mail: babakhanian.m@gmail.com

Authors' contribution/Wkład pracy autorów: Study design/Koncepcja badania: M. Babakhanian; Data collection/Zebranie danych: M. Ghazanfarpour, M. Babakhanian; Statistical analysis/Analiza statystyczna: A. Keshtkar; Data interpretation/Interpretacja danych: M. Babakhanian, M. Kiani; Acceptance of final manuscript version/Akceptacja ostatecznej wersji pracy: M. Babakhanian; Literature search/Przygotowanie literatury: M. Babakhanian

No ghostwriting and guest authorship declared./Nie występują zjawiska ghostwriting i guest authorship.

Submitted/Otrzymano: 08.05.2019 • Accepted/Przyjęto do druku: 29.02.2020

(c) 2020 Institute of Psychiatry and Neurology. Production and hosting by Termedia sp. z o.o.

This is an open access article under the CC BY-NC-ND license (http://creativecommons.org/licenses/by-nc-nd/4.0/) 
in PubMed, PubPsych, Scopus, Google Scholar, SID and Iranmedex, and other databases (for gray literatures, e.g. conference papers, key journals) for relevant CTs articles. We used the Cochrane Collaboration's checklist to assess the risk of bias, using random-effects model meta-analysis to combine data. The Grades of Recommendation, Assessment, Development, and Evaluation (GRADE) method was used to evaluate overall study quality. The primary and secondary outcomes were time spent on viewing pornography.

This paper is registered in PROSPERO (registration no. CRD42018107247).

Results: This study consists of three CTs articles with a total of 70 participants (39 in the non-treatment and 31 in the treatment group).

Random-effects model in meta-analysis were conducted with the results indicating a standard mean difference of 1.11 (95\% CI: -0.003 to $2.44 ; p=0.000$ ) between the two groups. This indicates an improvement in pornography-related problems. However, significant heterogeneity was observed in the meta-analysis. To identify the source of heterogeneity, we applied random-effects model in the meta-analysis separately to two studies that had adult men as their target population. According to the results, the standard mean difference between two groups was $1.71(0.97-2.44)$ and $I^{2}=0(p=0.7)$.

The results of meta-analysis on participants' quality of life exhibited a standard mean difference of -0.002 (95\% CI: -0.526 to 0.523 ) between the two groups, indicating the effect of ACT on boosting the participants' quality of life. Publication bias was assessed using Begg and Egger tests with a $p$-value of 0.1 and confidence interval of -14.3 to 24.8 . The results registered the absence of publication bias.

Conclusions: The findings exhibit that ACT has a positive effect on problematic pornography use and quality of life in patients.

Keywords: Acceptance and Commitment Therapy, Pornography, Systematic review, Meta-analysis. trolled Trials (CENTRAL), MEDLINE, PubMed, PubPsych, Scopus, Google Scholar, SID i Iranmedex oraz innymi bazami danych (dotyczącymi tzw. szarej literatury, np. artykułów z konferencji czy z kluczowych czasopism). Do oceny ryzyka błędu systematycznego użyto listy kontrolnej Cochrane Collaboration, a do łączenia danych - metaanalizy modelu efektów losowych. Ogólną jakość badań oceniano metodą GRADE. Podstawowe i drugorzędne wyniki to czas spędzony na oglądaniu pornografii.

Artykuł jest zarejestrowany w PROSPERO (nr rejestracyjny CRD42018107247).

Wyniki: Zakwalifikowano trzy artykuły dotyczące badań kontrolowanych, które obejmowały łącznie 70 uczestników (39 w grupie nieleczonych i 31 w grupie leczonych).

Metaanaliza modelu efektów losowych pokazała standardową średnią różnicę między dwiema grupami 1,11 (95\% CI: $-0,003$ do 2,44; $p=0,000$ ). Oznacza to poprawę problemów wynikających $\mathrm{z}$ oglądania pornografii. W metaanalizie zaobserwowano jednak znaczną niejednorodność. W celu zidentyfikowania jej źródła przeprowadzono metaanalizę modelu efektów losowych oddzielnie dla dwóch badań, w których byli badani dorośli mężczyźni. Standardowa średnia różnica między dwiema grupami wyniosła $1,71(0,97-2,44)$, a $I^{2}=0$ $(p=0,7)$.

Metaanaliza dotycząca jakości życia uczestników wykazała standardową średnią różnicę -0,002 (95\% CI: $-0,526$ do 0,523$)$ między dwiema grupami, co oznacza wpływ ACT na poprawę jakości życia uczestników. Stronniczość publikacji oceniano za pomocą testów Begga i Eggera $z$ wartością $p$ równą 0,1 i przedziałem ufności od $-14,3$ do 24,8 . Wyniki świadczyły o braku stronniczości publikacji.

Wnioski: Badania pokazują, że ACT wpływa na poprawę problemowego używania pornografii i jakości życia pacjentów.

Słowa kluczowe: terapia akceptacji i zaangażowania, pornografia, przegląd systematyczny, metaanaliza.

\section{- INTRODUCTION}

Addiction is not limited to drug abuse. Whenever a habit turns into a compulsion, it may be called addiction [1]. Internet, pornography and compulsivity have posed major problems over the past decade [2]. The World Health Organization has added problematic sexual behaviours to 
the forthcoming $11^{\text {th }}$ edition of the International Classification of Diseases [3].

Three to six percent of the general US adult population are estimated to meet the criteria for compulsive sexual behaviour (CSB) [4], though it is difficult to assess the prevalence of CSB on the internet to obtain accurate statistics [5]. This is mainly due to the ever-expanding number of internet users and the difficulty of monitoring activities on cyberspace [6]. There are only few empirical evidences about the Acceptance and Commitment Therapy (ACT) treatment and its positive effect on problematic pornography use (PPU). This is in part due to ambiguities surrounding, the conceptualisation, symptoms and underlying causes of this condition. Individual ACT sessions are psychological treatments involving the acceptance of this problem as a value context of committing the action in the present-day [7].

The definition of CSB proposed by Kafka relies on two major facets of behaviour. The first is the individual-based compulsive sexual behaviour that manifests in compulsive sexual thoughts, fantasies and vast amount of time spend on viewing pornography and masturbation. The second is partnered compulsive sexual behaviour that describes interpersonal sexual conquests, cybersex and pursuit of partners (this qualifies as "love addiction") [8].

The Adlerian standpoint on Problematic Internet Pornography Use underlines the clarification of the patient's lifestyle - the distinct model of each individuals' transition from a feeling of inferiority to that of superiority. There are several methods for lifestyle analysis, the two most important of which are tasks of life and family constellation. From an Adlerian standpoint, patients can understand the goal of their pornography viewing, clarify pathways that foster accountability for the process of change, and enable novel methods of dealing with the tasks of life [9].

This study seeks to investigate whether ACT is an effective treatment for people who report that lengthy pornography watching negatively affects their quality of life. Also, it sets out to review the effect of psychological intervention (ACT) on alleviating the PPU.

\section{- MATERIAL AND METHOdS}

\section{Review question}

Does ACT intervention aggravate/alleviate the symptoms in individuals with PPU?
This research is registered in PROSPERO under the code CRD42018107247.

\section{Search procedure}

We first reviewed related studies by searching in Cochrane and Prospero databases. Then, electronic bibliographic databases such as Cochrane Central Register of Controlled Trials (CENTRAL), MEDLINE in PubMed, Scopus, PubPsych, Google Scholar and SID and Iranmedex (Iranian database) were searched until 01.01.2018. In the end, we reviewed others databases (for gray literatures, e.g. conference papers, key journals). The search strategy was based on the following terms and phrases: "pornography", "internet pornography use", "online pornography", "internet sex addiction", "internet pornography", "cyberpornography" and ACT. The search was conducted in English and other languages.

\section{Participants/population}

The population consisted of all patients with PPU psychological disorder and as healthy control group that comprised male/female participants of different ages.

\section{Criteria for the selection of studies}

Inclusion criteria: studies with experimental design or CTs. Exclusion criteria: studies focusing on animals.

Intervention(s), exposure(s)

Psychological intervention, particularly ACT.

\section{Comparator(s)/control}

Given the nature of research, both controlled studies (studies without any treatment, with usual treatment, etc.) and within-subjects studies were included.

\section{Primary and secondary outcomes}

Pre- and post-intervention data consisted of measures focusing on the intensity of PPU, which included self-report behavioural viewing (e.g. self-reported hours of viewing per week or per month). The secondary outcome(s) contained the quality of life.

\section{Data extraction (selection and coding)}

Full text articles were reviewed based on eligibility criteria. Extracted information consisted 
of authors, year of publication, participants, sample size, primary outcome, secondary outcome, measures and findings. The authors were contacted if additional information was required.

\section{Risk of bias (quality) assessment}

Quality assessment was performed using the modified quality assessment checklist for clinical trial studies (Cochrane checklist). The checklist of each study was completed with two reviewers independently. The corresponding author and the first author assessed all studies that met inclusion criteria. Any discrepancies between ratings were resolved until a consensus was reached.

\section{- Results}

\section{Included studies}

After conducting the advanced search, 5 records were identified, and there were no duplicate records removed. Three full-text articles were assessed for eligibility. In the end, all 3 articles met the eligibility criteria to be included in the meta-analysis [10-12] (Figure 1). All three studies had employed Acceptance and Action Questionnaire (AAQ), adopted a measuring tool for PPU and had reported the quality of life data in their results (Table I).

\section{Study characteristics}

A total of three studies with a total of 70 participants (39 in the control group and 31 in the treatment group) were included in the qualitative systematic review (Table I). The CTs articles were published between 2010 and 2017, and their sample size ranged from 6 to 19 .

\section{Pornography viewing}

We applied a random-effects model in meta-analysis to the results of three studies. According to the results, the mean standard difference between the two groups (treatment and control) was 1.11 (95\% CI: -0.003 to 2.44 ), which was statistically significant $(p=0.000)$ and exhibited an improvement in the intervention group. However,

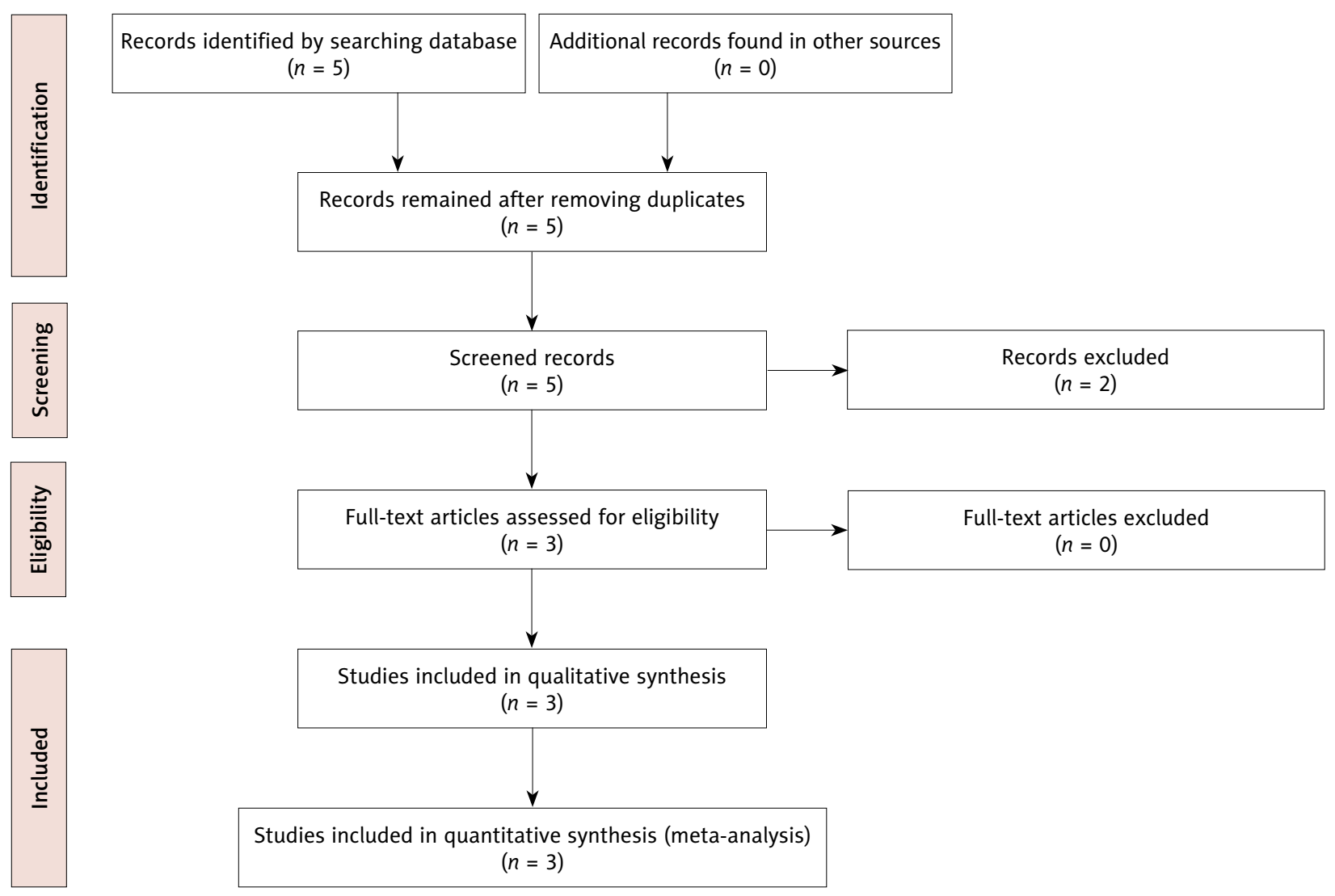

Figure 1. Review flowchart for primary study selection. Prisma 2009 Flow Diagram [13] 


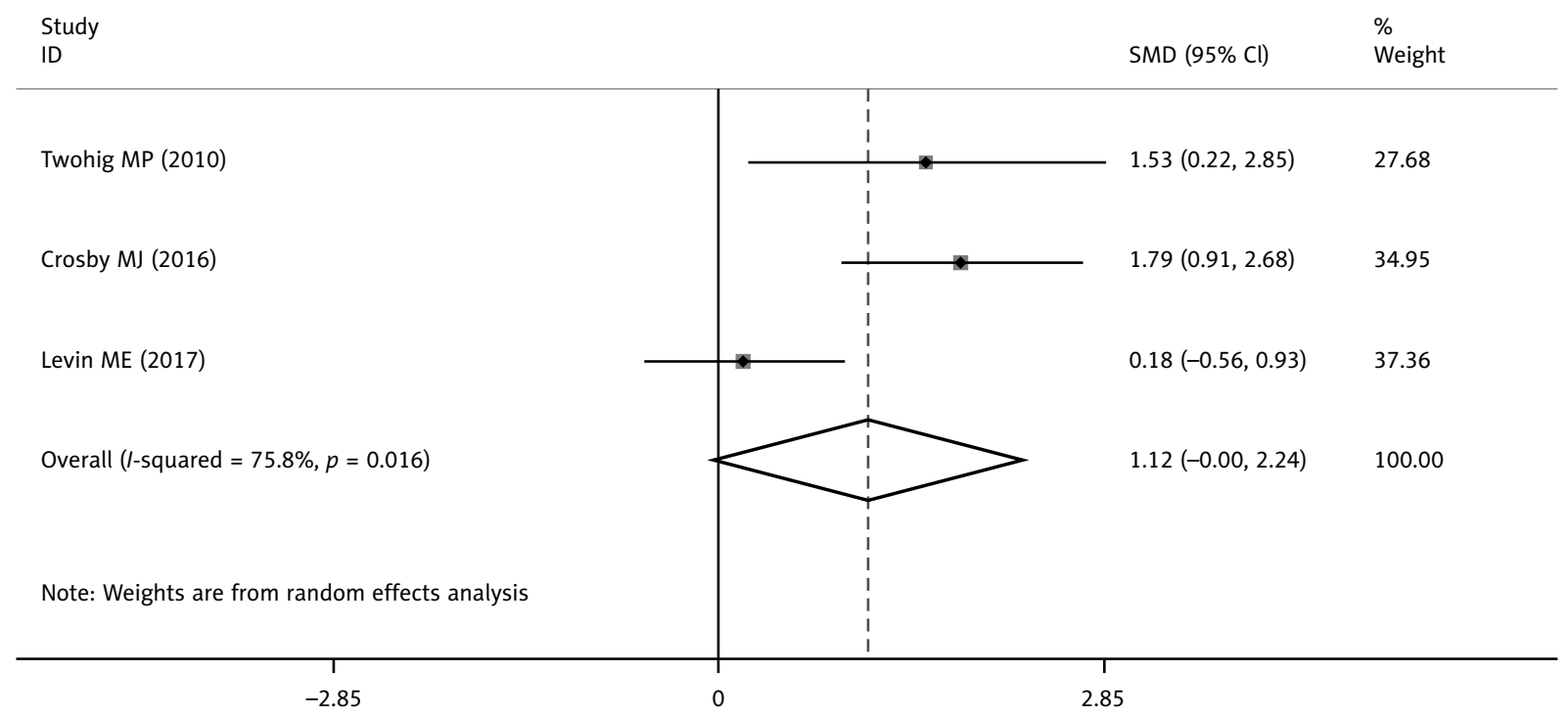

Figure 2. Efficacy of Acceptance and Commitment Therapy on minutes spent viewing pornography with random model

Table I. Study characteristics

\begin{tabular}{|c|c|c|c|c|c|c|c|c|}
\hline $\begin{array}{l}\text { Author } \\
\text { year }\end{array}$ & $\begin{array}{c}\text { Type } \\
\text { of study }\end{array}$ & $\begin{array}{l}\text { Target } \\
\text { groups }\end{array}$ & Mean age & Intervention & $\begin{array}{l}\text { Measuring } \\
\text { tool for } \\
\text { pornography } \\
\text { viewing }\end{array}$ & $\begin{array}{c}\text { Measuring } \\
\text { tool for life } \\
\text { quality }\end{array}$ & Outcome & $\begin{array}{c}\text { Quality } \\
\text { assessment }\end{array}$ \\
\hline $\begin{array}{l}\text { Twohig } \\
\text { MP, } \\
2010 \text { [7] }\end{array}$ & $\begin{array}{l}\text { Before-and- } \\
\text { after trial }\end{array}$ & $\begin{array}{l}\text { Adult } \\
\text { males }\end{array}$ & 26.5 & $\begin{array}{l}\text { Eight } \\
1.5 \text {-hour } \\
\text { sessions } \\
\text { of ACT }\end{array}$ & $\begin{array}{c}\text { Acceptance } \\
\text { and Action } \\
\text { Questionnaire } \\
\text { (AAQ) }\end{array}$ & $\begin{array}{l}\text { Quality } \\
\text { of Life } \\
\text { Scale } \\
\text { (QOLS) }\end{array}$ & $\begin{array}{l}\text { Reductions } \\
\text { in viewing } \\
\text { pornography } \\
\text { Increases in } \\
\text { measures } \\
\text { of life quality }\end{array}$ & Moderate \\
\hline $\begin{array}{l}\text { Crosby } \\
\text { MJ, } 2016 \\
{[8]}\end{array}$ & $\begin{array}{c}\text { Randomised } \\
\text { trial }\end{array}$ & $\begin{array}{l}\text { Adult } \\
\text { males }\end{array}$ & $\begin{array}{c}29.3 \\
(\mathrm{SD}=29.3)\end{array}$ & $\begin{array}{l}\text { Twelve } \\
1 \text {-hour } \\
\text { sessions } \\
\text { of ACT }\end{array}$ & $\begin{array}{c}\text { Acceptance } \\
\text { and Action } \\
\text { Questionnaire } \\
\text { (AAQ) }\end{array}$ & $\begin{array}{l}\text { Quality } \\
\text { of Life } \\
\text { Scale } \\
\text { (QOLS) }\end{array}$ & $\begin{array}{l}\text { Reductions } \\
\text { in viewing } \\
\text { pornography } \\
\text { Increases in } \\
\text { measures } \\
\text { of life quality }\end{array}$ & High \\
\hline $\begin{array}{l}\text { Levin } \\
\text { ME, } \\
2017 \text { [9] }\end{array}$ & $\begin{array}{l}\text { Before-and } \\
\text {-after trial }\end{array}$ & Adult & $\begin{array}{c}23.1 \\
(\mathrm{SD}=23.1)\end{array}$ & $\begin{array}{c}\text { Eight } \\
\text { sessions }\end{array}$ & $\begin{array}{c}\text { Acceptance } \\
\text { and Action } \\
\text { Questionnaire } \\
\text { (AAQ) }\end{array}$ & $\begin{array}{l}\text { Quality } \\
\text { of Life } \\
\text { Scale } \\
\text { (QOLS) }\end{array}$ & $\begin{array}{l}\text { Reductions } \\
\text { in viewing } \\
\text { pornography } \\
\text { Increases in } \\
\text { measures } \\
\text { of life quality }\end{array}$ & Moderate \\
\hline
\end{tabular}

the studies were significantly heterogeneous for the homogeneity index. In Figure 2, the midpoint of each line segment shows the mean and the line segments indicate a confidence interval of $95 \%$ for each study. The diamond sign shows the average betterment in the three studies. As shown in Figure 2, the findings manifest the positive effect of ACT therapy on decreasing the hours of viewing pornography per week.

To identify the severe heterogeneity factor, the random-effects model in meta-analysis was ap- plied to two studies conducted by Crosby [8] and Twohig [10]. According to the results, the standard mean difference between the two groups was $1.71(0.97-2.44)$ and the total value of $I^{2}$ was 0 $(p=0.7)$.

\section{Quality of life}

The random-effects model in the meta-analysis was applied to two studies [11, 12], which explored 46 subjects to investigate the effect of ACT 
Table II. Primary study quality (risk of bias)

\begin{tabular}{|l|c|c|c|c|c|}
\hline Author & Selection bias & Random allocation & Attrition bias & Confounding control & Quality \\
\hline Twohig MP, 2010 & Moderate & Low & High & Low & Very low \\
\hline Crosby MJ, 2016 & High & High & High & Moderate & Moderate \\
\hline Levin ME, 2017 & Moderate & Low & High & Low & Very low \\
\hline
\end{tabular}

Table III. Grade of recommendation, assessment, development and evaluation (GRADE) quality of evidence for primary and secondary outcome

\begin{tabular}{|c|c|c|c|c|c|c|c|c|c|}
\hline \multirow{2}{*}{ Outcome } & \multirow{2}{*}{$\begin{array}{l}\text { No of } \\
\text { study }\end{array}$} & \multirow{2}{*}{$\begin{array}{l}\text { Risk } \\
\text { of bias }\end{array}$} & \multirow{2}{*}{$\begin{array}{l}\text { Inconsis- } \\
\text { tency }\end{array}$} & \multirow{2}{*}{$\begin{array}{l}\text { Indirect- } \\
\text { ness }\end{array}$} & \multirow{2}{*}{$\begin{array}{l}\text { Impreci- } \\
\text { sion }\end{array}$} & \multicolumn{2}{|c|}{ No of patients } & \multirow{2}{*}{$\begin{array}{c}\text { Effect } \\
\text { SMD }(95 \% \mathrm{Cl})\end{array}$} & \multirow{2}{*}{ Quality } \\
\hline & & & & & & Intervention & Control & & \\
\hline $\begin{array}{l}\text { Viewing } \\
\text { porno- } \\
\text { graphy }\end{array}$ & 3 & Low & High & Low & High & 39 & 31 & $\begin{array}{c}1.11 \\
(-0.003 \text { to } 2.24)\end{array}$ & Moderate \\
\hline $\begin{array}{l}\text { Life } \\
\text { quality }\end{array}$ & 2 & Low & High & Low & High & 46 & 37 & $\begin{array}{c}-0.002 \\
(-0.526 \text { to } 0.523)\end{array}$ & Moderate \\
\hline
\end{tabular}

therapy on life quality. The results demonstrated that the standard mean difference between the two groups was -0.002 (95\% CI: -0.526 to 0.523 ), which is statistically significant $(p=0.000)$, indicating the effect of ACT on improving the participants' quality of life. As for the heterogeneity index, $I^{2}$ was $0.0 \%$, which reveals the absence of heterogeneity.

\section{Publication bias}

Publication bias was assessed using Begg and Egger tests. The $p$-value $(0.1)$ and confidence interval (-14.3 to 24.8) exhibited the absence of publication bias in findings.

\section{GRADE}

We used the Grades of Recommendation, Assessment, Development, and Evaluation (GRADE) method to rate the overall quality of evidence. In general, the ACT approach seems to be feasible and effective for the analysis of pornography viewing. This study offers empirical evidence that support the effectiveness of the proposed intervention for PPU, underlining the necessity of further research on this problem.

However, the low quality of evidence showed that the application of ACT may decrease viewing pornography time and increase the quality of life. We downgraded the level of evidence due to a risk of detection bias (risk of bias), inconsistency, indirectness and imprecision (details of judgment are shown in Tables II and III).

\section{- Discussion}

The findings of this study suggest that ACT intervention positively affects life quality and reduces pornography viewing time.

ACT intervention have been demonstrated to be as successful in reducing PPU. By turning the patient's attention to her/his behaviour, thoughts and experiences in problematic pornography behaviour, it can decrease the hours of pornography viewing. The result align well with other studies $[2,14]$.

The quality of life is increasingly related to the level of public health and determining the factors that have a bearing on decisions related to public health policies [15]. Given that too much viewing of pornography reduces life quality [15], ACT can diminish the distresses of pornography problems by changing feelings and controlling habits, which in turn contributes an improvement in patients' life quality $[2,16]$.

To explain the marked heterogeneity among studies, a meta-analysis was undertaken on two studies by Crosby [11] and Twohig [10]. These two studies examined adult Caucasion men in USA from among an exclusive target population of Christians (i.e. the Church of Jesus Christ of Latter-day Saints). It is crucial to look further in this topic by concentrating on the recognition of desires to view and adhering to one's values as a suitable way of decreasing viewing time. Therefore given the slight variations in participants, future research can focus attention on how to improve the therapeutic efficacy by considering other behaviour treatment techniques. 


\section{Strengths and limitations}

There are several strengths to this study. First, it is the first systematic review and meta-analysis of clinical trials to explore the effects of ACT on treating PPU. Second, we performed a comprehensive search of the largest and most exhaustive databases for relevant randomised controlled trials (RCTs). Third, all included RCTs were assessed by the Cochrane Collaboration's tool for the risk of bias and fourth, the GRADE approach was adopted to evaluate the strength of evidence for each outcome.
However, there were a number of limitations to our meta-analysis. First, due to the paucity of existing studies, we were unable to conduct all of the expected subgroup analyses. Second, as Thorlund et al. said "if meta-analyses are performed too early, before enough studies are available, there is a danger that incorrect conclusions may be drawn and recommend therefore that results from underpowered meta-analyses are interpreted with caution" [17].

Third, two of the three included studies had evaluated outcomes in patients without considering a control group.

\section{Conflict of interest/Konflikt interesów}

None declared./Nie występuje.

Financial support/Finansowanie

None declared./Nie zadeklarowano.

\section{Ethics/Etyka}

The work described in this article has been carried out in accordance with the Code of Ethics of the World Medical Association (Declaration of Helsinki) on medical research involving human subjects, Uniform Requirements for manuscripts submitted to biomedical journals and the ethical principles defined in the Farmington Consensus of 1997.

Treści przedstawione w pracy są zgodne z zasadami Deklaracji Helsińskiej odnoszącymi się do badań z udziałem ludzi, ujednoliconymi wymaganiami dla czasopism biomedycznych oraz z zasadami etycznymi określonymi w Porozumieniu z Farmington w 1997 roku.

\section{References/Piśmiennictwo}

1. Love T, Laier C, Brand M, Hatch L, Hajela R. Neuroscience of internet pornography addiction: a review and update. Behav Sci (Basel) 2015; 5(3): 388-433.

2. Twine SL. ANCOVA Study of Psychotherapy Treatment of Internet Pornography Addiction in Heterosexual Men. Fidei et Veritatis: The Liberty University Journal of Graduate Research 2016; 1(1): 3.

3. World Health Organization. International Classification of Diseases for Mortality and Morbidity Statistics (ICD-11MMS); 2018.

4. Kuzma JM, Black DW. Epidemiology, prevalence, and natural history of compulsive sexual behavior. Psychiatr Clin North Am 2008; 31(4): 603-11.

5. Derbyshire KL, Grant JE. Compulsive sexual behavior: a review of the literature. $J B e-$ hav Addict 2015; 4(2): 37-43. DOI: 10.1556/2006.4.

6. Ross MW, Månsson SA, Daneback K. Prevalence, severity, and correlates of problematic sexual Internet use in Swedish men and women. Arch Sex Behav 2012; 41(2): 459-66.

7. Wéry A, Billieux J. Problematic cybersex: conceptualization, assessment, and treatment. Addict Behav 2017; 64: 238-46.

8. Kafka MP. Hypersexual disorder: a proposed diagnosis for DSM-5. Arch Sex Behav 2010; 39(2): 377-400.

9. Fall KA, Howard RC. An Adlerian perspective on problematic internet pornography use. J Individ Psychol 2015; 71(3): 273-89. 
10. Twohig MP, Crosby JM. Acceptance and commitment therapy as a treatment for problematic internet pornography viewing. Behav Ther 2010; 41(3): 285-95.

11. Crosby JM, Twohig MP. Acceptance and commitment therapy for problematic Internet pornography use: A randomized trial. Behav Ther 2016; 47(3): 355-66.

12. Levin ME, Heninger ST, Pierce BG, Twohig MP. Examining the feasibility of acceptance and commitment therapy self-help for problematic pornography viewing: Results from a pilot open trial. The Family Journal 2017; 25(4): 306-12.

13. Moher D, Liberati A, Tetzlaff J, Altman DG. The PRISMA Group Preferred Reporting Items for Systematic reviews and Meta-Analyses: The PRISMA Statement. J Clin Epidemiol 2009; 62: 1006-12.

14. Sniewski L, Farvid P, Carter P. The assessment and treatment of adult heterosexual men with self-perceived problematic pornography use: A review. Addict Behav 2018; 77: 217-24.

15. Griffiths S, Mitchison D, Murray SB, Mond JM. Pornography use in sexual minority males: Associations with body dissatisfaction, eating disorder symptoms, thoughts about using anabolic steroids and quality of life. Aust N Z J Psychiatry 2018; 52(4): 339-48.

16. Wetterneck CT, Burgess AJ, Short MB, Smith AH, Cervantes ME. The role of sexual compulsivity, impulsivity, and experiential avoidance in internet pornography use. Psychol Rec 2012; 62(1): 3-18.

17. Thorlund K, Imberger G, Walsh M, Chu R, Gluud C, Wetterslev J, et al. The number of patients and events required to limit the risk of overestimation of intervention effects in meta-analysis - a simulation study. PLoS One 2011; 6: e25491. 